\title{
CCBM-TRAILS: Cross-Cultural Business and Virtual Team Communication Training Platform
}

\author{
Martin Koplin ${ }^{1}$, Jochen Schiffmann ${ }^{2}$, Simone Müller ${ }^{3}$, Helmut Eirund ${ }^{4}$, Jutta Berninghausen ${ }^{5},{ }^{2,5}$ Centre for \\ Intercultural Management of the University of Applied Sciences Bremen, Martina Fetting ${ }^{6},{ }^{1,3,4,6}$ M2C Institute of \\ Applied Media Technology and Culture Bremen
}

\begin{abstract}
TRAILS is a cross-cultural business and virtual team communication training and eLearning platform based on a highly experienced blended learning methodology. It consists of analysis, awareness and training tools. It is the result of the current research and development at the $\mathrm{M} 2 \mathrm{C}$ Institute of Applied Media Technology and Culture Bremen and the Centre for Intercultural Management of the University of Applied Sciences Bremen. The project is a result of the "Smart Cities Smart Culture - Smart Humans" strategy of the European "Think BETA - Evolution of Smart Cities" think tank for research and development, funded by the German Federal Ministry of Education and Research - International Office (BMBF).
\end{abstract}

Keywords: Intercultural Management, International Business Coaching and Training, Organizational Development, Virtual Team Training

\section{INTRODUCTION}

High Mobility against the background of increasing global networks based on economy and media characterizes future dimensions of intercultural communication, especially in virtual working environments. Intercultural competence is considered to be a key qualification; in combination with virtual competencies it appears as a vital factor of success. European institutions and enterprises are instrumental in European integration and international economic actions. They lead the field in the global development and dissemination of technical products, infrastructures, services and logistics. Also in technical sectors the export of services, knowledge and methodologies rises. Recent studies of the Deutsche Gesellschaft für Internationale Zusammenarbeit (GIZ) (International Development Unit of the German Federal Government), the German Federal Ministry of Economics and Technology (BMWi) and the Federal Ministry for Economic Cooperation and Development (BMZ) point to deficits regarding know-how of intercultural networking and its implementation in technically supported virtual cooperation between global actors. This lack of knowledge transfer foils the otherwise higher-than-average professional competencies of European players. However, former approaches disregarding the current state of research have not anticipated the technical visualization of an increasing share of intercultural communication. To close this gap, TRAILS and the further research and development of the CCBM - CrossCultural Business and Virtual Management Communication Analyzing and Awareness Tool - join and integrate applied research and development of digital tools with individually designed integrative methods of media-supported learning. Only this technical and methodological interconnection allows solving huge deficits regarding the quality of management, communication and apprehension in such a way that economic efficiency as well as sustainability in social, political and cultural concerns of global players can be augmented considerably. TRAILS plays in the area of cultural, organizational and educational development within the think tank Think BETA. Think BETA is about the design of future technical and cultural infrastructure for smart cities, smart culture and smart humans. It is also about the optimization of work processes, municipal services and infrastructure for intercultural, virtual and diversity management optimization.

\section{OVERVIEW OF CCBM-TRAILS}

Online collaborations at work have the potential to trigger and shape significant changes within the working environment in a way future societies will function. Modern technologies enable the companies' personnel to communicate actively and interdisciplinary at an international level, over wide distances and beyond cultural borders. At the same time, virtual crosscultural work means to participate in the social development and decision processes of your social collaboration, thereby shaping its social environment [1]. The quality of the development and decision processes can be identified within the whole spectrum starting from nearly no-hopers to an exiting and efficient creativity between the participants of a team process. In all scenarios, the modality of participation and interaction strongly influences the quality of exchange. The innovative potential of the TRAILS tool lies in the option to develop novel instruments and methodologies for analysis and learning within intercultural and virtual working environments. Examples are the Intercultural Competence Screening, the Intercultural Preference Profile, the Intercultural Preference Leadership Profile, the Virtual Team Development Model, the Virtual Team Competence Analyser, the Virtual Emotional Leadership Profile etc. The results of these analyses are integrated pin pointedly at several levels into new Blended-Learning-Approaches in order to tap so far idle potentials between digital media and new learning methods and to create new opportunities for applicationoriented learning with auditory, visual and interactive aspects. Existing methods, e.g. the Critical Incident Method or the Cultural Assimilator, are refined; via multimedia and mobilized technology they advance the learning process onto a higher level. Due to the learning platform modular 
$2013 / 24$

construction, its content and size can be modified and adapted to the needs of the respective target group at any time. The TRAILS tool also functions as a pre-stage advisory service in favour of organizational work optimization. Within the TRAILS project, possible uses and practical applications are developed and advanced in cooperation with coaches and consultants to be utilized in a future CCBM System. The enduser will accomplish tasks within the sectors of virtual work streams, social navigation and intercultural acting in an optimized way. The further qualification of coaches and consultants will be supported and vitalized by the intercultural interaction between experts communicating about technical and methodological learning components. It is envisaged that in the future the project will evolve into a multilingual, multifunctional European tool, ready for implementation all over Europe by academic training schedules and professional development programmes for managers in industry, business and NGOs. In July 2012, the TRAILS project already received the Certificate "Best of 2012" in the category "IT Innovation" granted by the German Initiative Mittelstand (German Medium-Size Business Association). Actual and future working structures integrate across various locations of teams and individuals from business, science and art/design/culture.

"Virtual teams, modular structures, inter-organizational networking, increasing globalization, and the resolution of temporal and spatial constraints make different demands on leadership and cooperation" [2].

According to Ulrike Heinz, distributed teams and modular structures also require the appropriate allocation of tasks, a goal-oriented coordination and the pooling of the individual results. This can be improved by the stabilization and structural compaction of the cooperation. In addition to the moderation of these processes, motivation of those involved also is of significant importance "Instead of strictly defined communication structures, at classical hierarchical levels the direct exchange processes of groups and their members appear, which are not intensively directed, so the structured and organized labour and cooperative environment is attributed necessary flexibility and achievement that is necessary in the new competitive environment (...). This new leeway to change the tasks of leadership: relationship-oriented issues, such as integrative and communication skills, networking skills and competency, building trust and collaboration in a team and relationship management, comes to the fore"[2].

\section{Virtual TEAMWORK}

The advancement of information and communication technologies and their effect on culture reproduce new forms of virtual communication and enable the development of boundless cooperation in the broadest sense [3]. Conventional boundaries as the bondage of space, time and, therefore, also cultures fall away in the intercultural virtual collaboration. Distributed teams can achieve together their goals with few resources (time, personnel, and equipment). This new form of cooperation opens up many new opportunities, not only for companies in the light of the rising globalization and increased competition and cost pressures, but also for the field of research. The form of virtual work and here used media technologies will be further investigated in order to lay the foundations for future demands in training. The focus here is on the basic idea behind the development of the learning platform to a global service. This includes the integration of work in virtual teams and conducting distance education leadership, media, communication and participation, as well as training in intercultural management and diversity. In the export sector, European companies work increasingly with their expatriates, employees in remote offices, international partners and external experts in the so-called virtual teams. (Also for non-ICT university students, the targeted training to work in virtual teams is often something new). Concerning the media-based participation through feedback systems and intranet, new opportunities appear for learning organizations to improve work environment and processes. For this purpose, specially trained staff and managers are provided with useful knowledge, coaching and advice. Organizational difficulties that may arise at the beginning should be easily coordinated by the well-trained personnel [4]. The learning platform is at the seed and start-up phase of virtual team structures, and the flow of participation projects is a suitable tool for knowledge creation. Combined with the advice to build virtual and crosscultural teams and the process-related coaching, it will appear as an excellent service to raise awareness of the virtual team stakeholders and virtual team leadership representatives. The same applies to the integration of participatory processes and intercultural management training. New measures are efficient in enterprises thanks to the possibility of individual preparation of the e-learning modules. CCBM-TRAILS offers an advanced blended learning concept, which combines all the benefits of classroom training and e-learning and also serves as a tool that accompanies business management and teamwork. The integration of today's skills from media use, gaming, international communication and cultural diversity in daily live experience is at least of the same importance compared to the social use of new technologies and software systems. Actual training activities for intercultural competence and virtual teams transfer knowledge from research partners and scientific coaches to individuals and companies for their professional approaches.

\section{A. Future Technological Changes in the Use of Media Technology in International Work Scenarios}

Actual e-learning, communication, gaming and social software share a lot of basic technology features with IT systems that are developed for virtual teams. From virtual teamwork we already know technologies for ad-hoc communication, document management or secure access to workspace through cloud services. In this subsection we focus on the classification of these technologies with respect to blended learning scenarios.

\section{B. Ad-hoc Communication Services and Technology}

Instant massaging like ICQ came up in the mid-1990s starting with simple text messages (chatting). With more available bandwidth, other services were added such as file exchange 
and audio messages (voice over IP, i.e., internet telephony like Skype). They are useful for remote teams that work synchronously and provide fast and easy access to tutors or learners. To share the whole desktop content (e.g. presentations, drafts or results of exercises) small clients must be installed on all participating PCs. Typically, a session is moderated and access rights must be defined for remote actions. Video conferencing, which was the aim of many research projects already in the 1970s, did not have affordable bandwidth and computational power until new compression algorithms and simple tools for setting up conferences came in use in the last few years. With Microsoft NetMeeting, for example, a videoconference can be set up, data can be viewed via whiteboard functions and desktop content can be shared. Also Skype is used worldwide for videoconferences. A great example for an easy setup system with acceptable quality for up to eight participants is Hangout in Google + . While other conference tools need special clients to be installed, G+ works through the browser interface - nothing must be installed on the client side (but the browser). A conference can share any desktop application of a participant (e.g., a presentation) and can be stored as a youtube-stream for later reuse as a stream. This is extremely useful both in virtual classroom scenarios and in remote teams that work synchronously.

\section{Document Management}

While whiteboard data exchange and file sharing in conference tools facilitate ad-hoc document sharing, document management systems (DMS) support a much higher level of organizing documentation (literally, documents). Documents in virtual teams establish results in teamwork or - mapped to blended learning scenarios - may store learning outcomes, exercise results or evaluations. Virtual teams or learning groups may work together on one document. Thus, a DMS must have elaborated access right management with different levels of access and a check-in-check-out mechanism for asynchronous work. A version management allows stepping through earlier stages of the document(s). Within synchronous work scenarios, even branches of versions may be supported. Those versions in parallel branches may be merged again latersupported by the DMS. Systems like SVN (Subversion), Git or Microsoft SharePoint support these features of DMS.

\section{Availability of Services and Data in Cloud Services}

Besides the access to shared data, cloud services provide applications and computational power through web services. These new kinds of service distribution require secure authentication mechanisms and licensing techniques for proper accountancy of service usage. Advantage for teams is the availability of applications that may be needed only for short time durations and at remote places - both true for virtual teams and learning scenarios. Cloud services hide the implementation of storage or provision of services - users do not need to know how or where the used data or applications are stored. Especially in mobile application scenarios, where access must be assured at any place, even with low bandwidth and computational power on the client system, cloud services are highly interesting and useful.

\section{E. Virtual Teams in Today's Working Practice}

The main training goal for virtual teamwork in enterprises is the enhancement of interdisciplinary knowledge integration in order to succeed in international markets and to develop new innovation potentials, especially in combination with cross-cultural training for actual working practice.

\section{F. Advantages and Benefits of Virtual Collaboration}

Virtual collaboration can offer significant advantages over traditional local, e.g., on-site collaboration in many ways and creation of a significant added value in such areas as expenditure, flexibility, networking and innovation. Lower travel, training and meeting costs, offshoring to involve specialists in low-cost countries, connecting experts from various areas to integrate diverse knowledge and perspectives resulting in an increased level of innovation and creativity are only a few examples of the benefits of virtual teamwork. The expansion of cooperative relationships can increase not only the degree of interconnectedness, but also the attractiveness and reputation of companies. In other words, the extension of collaboration partners can become an important factor for further contracts or employee retention thanks to the perceived (outside) image [5].

\section{G. Challenges in Virtual Collaboration}

However, studies on teamwork in virtual environments show the other side of the coin. In general, a key challenge for the members of a virtual organization is certainly the significant increase in coordination requirements and rework efforts [6]. A new virtual collaboration starts without an established standard for general work processes or project management, which results in an increased effort to define clear guidelines for communication standards, norms for decision-making or problem-solving, best practices for working processes, meetings or structures for data storage and knowledge management. Another challenge for virtual collaboration is the creation of an emotional bond or relationship among the individual members. It is not only more difficult and takes more time to build trust in a virtual environment than in an on-site team. Moreover, it is more difficult in virtual collaboration to create a sense of togetherness or cohesion, especially in virtual networks or loose conglomerates with different intentions and motivations of the partners involved, not to mention the diversity in corporate, organizational or national cultures. Often there is the lack of identification with a common group goal and consequently reduced commitment to the group. Major challenges that significantly affect the success of collaboration in a virtual environment are the following: to develop common goals and to ensure the common understanding of the objectives.

A virtual team is faced with an increase in misunderstandings and conflicts that can have different root causes. Examples are culturally-induced conflicts due to the lack of understanding of the cultural differences or mediainduced conflicts due to increased transparency, accelerated 
communication, reduced perceptual channels or the lack of contextual information about the personal and environmental perspectives of other members. However, not only the increased potential for a conflict is a challenge, but also the reduced means of conflict resolution are often undervalued. Manager or leaders of a virtual team, an organization or a loose network face additional challenges. Besides the abovementioned organizational and procedural aspects of the mediabased cooperation, cultural integration and team building and development, a distance leader is also defined by his/her role as a coordinator and facilitator. However, the personalized leadership elements are minimized by the reduced latency of influence and control capabilities. Compared to a traditional collaboration, a virtual environment is characterized by a lower degree of influence and even loss of control.

The increase in improved Information and Communication Technologies (ICT) not necessarily brings about the "death of distance". Even though there is limitless technical access (connection) between the virtual workforces, the potential benefits of the virtual collaboration can be negated by the technologies that made this setting possible, as the virtual team members often perceive a virtual distance (disconnection) between them, called the Connectivity Paradox. An American study has shown that a high degree of virtual distance in project teams leads to the reduced role and goal clarity, decreased job satisfaction, reduced trust, declined leadership effectiveness, declined innovative capacity, and a reduction in the overall project success [7].

\section{H. Factors for Successful Virtual Collaborations}

Training for virtual teams is very often focused on the technical aspects of virtual teamwork; however, peopleoriented soft factors, such as building trust, are the key to ensure a successful virtual teamwork [7]. The key success factor "culture", e.g., the way how multi-cultural aspects are reflected in the operation and communication of virtual team is discussed separately in Section 4.

\section{Technology: Use of Technology-Based Collaboration and Communication Tools}

The ability of the individual members to effectively operate in the virtual context is a prerequisite for successful virtual teamwork. Examples of required core competencies are the skilled use of the appropriate technology for communication, coordination and collaboration or the knowledge of the etiquette, when using the different types of ICT. Examples of appropriate communication skills include the provision of contextual information and the promotion of feedback processes. A cornerstone for virtual collaborations is the virtual meeting, which is not only a means of work organisation in a virtual environment A virtual meeting also provides a good opportunity for personal interaction and social topics, since it is often the only way of exchange and establishing common ground for the virtual team members [8]. The ability to carefully plan and facilitate a virtual meeting is an important factor for successful virtual collaboration.

\section{J. Virtual Work: Working Structures and Standard Work Processes}

The working structures of virtual collaboration need to be carefully chosen depending on parameters such as the common goal, roles and responsibilities or the necessity to integrate changing members and to diverse legal requirements. The analysis of these aspects results ideally in an appropriate governance structure and adequate choice of ICT that supports the virtual collaboration according to its requirements. The increased degree of integration (different locations, organization, cultures etc.) demands a continuous exchange, which can be secured by standard processes. Developing "Best Practices" for work processes, such as decision-making, problem solving, information sharing, knowledge management, data storage or communication, helps reduce the amount of compensation of organizational differences and generates a common working ground. Studies have shown that there is a much higher potential for a conflict regarding undefined processes in virtual teams than in traditional teams. Due to the increased complexity in a virtual working environment, the focus on process management is a key success factor [9].

\section{K. Relationship-Oriented Factors: Team Building, Trust and Conflict Management}

A sense of community and a strong group identity are important factors for effective collaboration. The lack of daily contact with each other requires an active focus on factors such as the importance of the common working objectives and the mutual understanding between the members. In on-site teams, implicitly and jointly occurring team development processes require explicit implementation in a virtual environment through establishment of a team identity, team culture, shared vision and trust building activities. Trust can be defined as the confidence or belief in the integrity, fairness and reliability of a person or an organization [10]. Trust is often built by sharing personal information and the discovery of similarities (e.g., family, hobbies, etc.), which can in a traditional setting easily happen on the fly. However, conventional approaches to build trust in collaboration are often not effective in virtual environments due to the lack of a direct face-to-face shared experience. Another relationshiporiented factor for successful virtual collaboration is adequate conflict management. Virtual collaboration requires constructive conflict management with conflict resolution strategies adapted to the virtual context. Hence, every team member must be alert to the increased potential of issues and misunderstandings, as well as skilled in the limited conflict solving mechanism [11].

\section{Distance Leadership: Leadership Skills and Individual Competencies}

Managers of virtual teams are challenged by overcoming the physical, functional, cultural and emotional distance of the team members while their cooperation, communication and leadership activities are mainly based on ICT. A particular challenge of the leadership function in a virtual environment is the performance monitoring and assessment. The performance 
and delivery grade of each member are often less or even not visible through the technology filter. The specific context of delivery, i.e., the local knowledge required to assess the quality and correctness, is often unknown. In addition, the management of "independent" members in a virtual organization is particularly difficult due to the lack of "given power" compared to a hierarchical organizational structure, e.g., the hierarchical power and control concept does not work well in a virtual environment. Therefore, Distance Leadership is often seen as "leadership by all members of the team" fostered by the technology-based collaboration tools [12]. Each member in virtual collaboration must, therefore, take responsibility and "ownership" for his/her own area, if not even forming his/her own separate, conductive unit. Consequently, each virtual team member has to fulfil certain aspects of leadership activities, e.g. playing an active part in building trust, creating context or co-activating other members. Individual competencies mainly assigned to leaders in on-site teams, such as networking, spanning boundaries across organizations or self-management, are also prerequisites for each member in a virtual team to ensure successful collaboration.

\section{Prospects for the Future}

Current developments suggest that our working environment will significantly change in the future. In addition to the continuously enhanced ICT and the proceeding globalization, which both will change the way we work, also the demographic change will have a major impact. Today's companies, which are faced with the generation Y workforce, are changing their virtual and physical working environments to integrate the new requirements: increased diversity, better work-life balance or the focus on employees' participation, to name a few. The CCBM-TRAILS uses neuro-emotional analysis methodologies for team leaders and members to assess their capacities, strengths and weaknesses and development needs. The organizational performance of crosscultural and possibly interdisciplinary virtual teams is highly embedded in differing aspects of culture, leadership and organizational culture of their members. Its excellence is based on the quality of the training and coaching of these teams.

\section{Cross-Cultural Boundaries IN TEAmwork}

The number of international mergers and acquisitions, as well as the number of international corporations, has enormously increased over the past year. This growth requires intense teamwork from professionals of different cultural backgrounds. Cross-cultural conflicts are often underestimated and can lead to frustration. Culturally related differences can be an obstacle for effective work. It is not easy to recognize these barriers. Once recognized, they probably have already caused damage. Improper behaviour on the part of the manager may cause even more problems, which he or she will not be able to solve. Leading a multicultural team is a real challenge. It is about knowing the cultural backgrounds that might be problematic and recognizing them as an issue. In the long term, team members shall solve intercultural problems themselves. In most human resource departments and at higher levels of management, the awareness of cross-cultural training is growing as a result of failed international projects that have led to extensive economic losses.

\section{A. Cross-Cultural Training for Actual Working Practice}

Since the 1990s, more and more enterprises have realized the value of intercultural training for their employees. Intercultural competence is now known as a key competence in soft skills and is placed at the top of the agenda of many enterprises in the sector of human resources. As a quite young discipline, the most common methodological approach is the classical face-to-face training. Training instruments are case studies, role-plays or group exercises. E-learning and blended learning have not been used in training yet. A few attempts have been made to use communication technologies and new media in training, but the potential of these technologies has not been fully exploited. CCBM-TRAILS project tries to turn all these deficits into benefits for the cross-cultural training sector, also by considering the demands of future training. One of the tasks here is to connect the state-of-the-art technologies with the scientific approach for intercultural competence and create a new user experience and acceptability. Not only by means of the common methods of e-learning, such as drag and drop, single and multiple choice questions, interactive graphics, animations or different combinations of these methods, but also by the use of already existing online communication methods, such as discussion forums, chats, blogs or video-blogs, all the training methods can be advanced to a new state of art. Additional methods, such as the direct contact to people from other cultures, can also be integrated. This leads to direct effectiveness of the training and applies all the more theoretical issues into practice. As a consequence, training becomes more and more authentic, offering new ways for dealing with cross-cultural differences.

\section{B. Methodologies for Intercultural Competence Training}

In the context of scientific research and practice of the last decades, theoretical models of intercultural competence were continuously developed. Primary register models, which described intercultural competence according to a construct of different personality traits, were formed as structure models that divided the register into three different levels: affective, cognitive and conative. Nowadays, process models are used to describe intercultural competence. This takes place at the interaction and impact of the three levels with each other according to the context. Based on a model by Darla Deardorff [13], a new model was created for the CCBM-TRAILS project that included the three levels (affective, cognitive and conative). This is also the scientific training approach of the ZIM. The model shows the consistent process of developing intercultural competence. At each point in the model, a learning process can be established. The model also shows the interaction and impact between the components. 


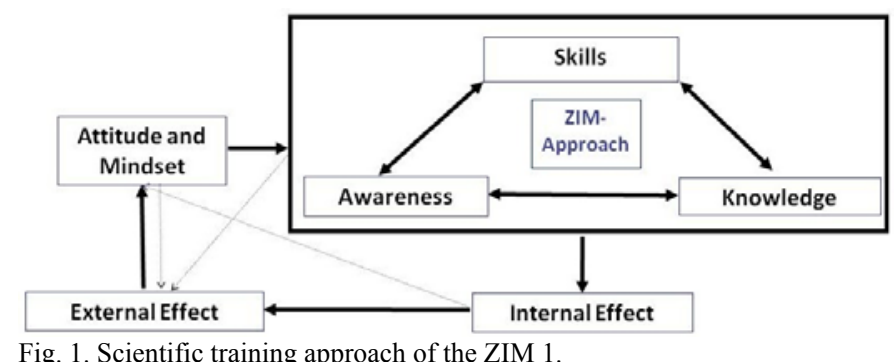

Fig. 1. Scientific training approach of the ZIM 1.

Attitude and mindset (motivational level): appraisal, openness, lack of bias, flexibility, emotional stability, selfreflection, empathy.

The scientific training approach consists of the following elements [14]:

Awareness (affective level): cognition awareness, cognition of different communication patterns, cognition of stereotyping and prejudice;

Knowledge (cognitive level): cultural appreciation, knowledge about different communication patterns and strategies, knowledge of their own (cultural) values, knowledge of cultural differences, knowledge of stereotypes and prejudice;

Skills (conative level): interpretation skills, communication skills, conflict skills;

Internal effect: displacement of one's own reference frame, ability to adapt, flexibility, providing one's own ethnocentric point of view;

External effect: effective communication and adequate behaviour in cross-cultural situations.

The model clearly shows that the term "intercultural" is a dynamic concept, which is steadily in process. It is a direct result of any learning experience, for example, a trip to a foreign country or a cross-cultural training. It is also a complex learning and experience process, which takes place at different levels. Therefore, cross-cultural learning should not be oriented to separate knowledge components. Rather, the appreciation of the whole context which leads to a better understanding of cultural differences should be developed. The process model has been extended with a pyramid model that is also adapted from Darla Deardorff [13]. Hereby, the attitude and mindset is the base for intercultural competence so that the required awareness, knowledge and skills can be developed. As a consequence of these two levels, the internal and the external effect follow the pyramid model.

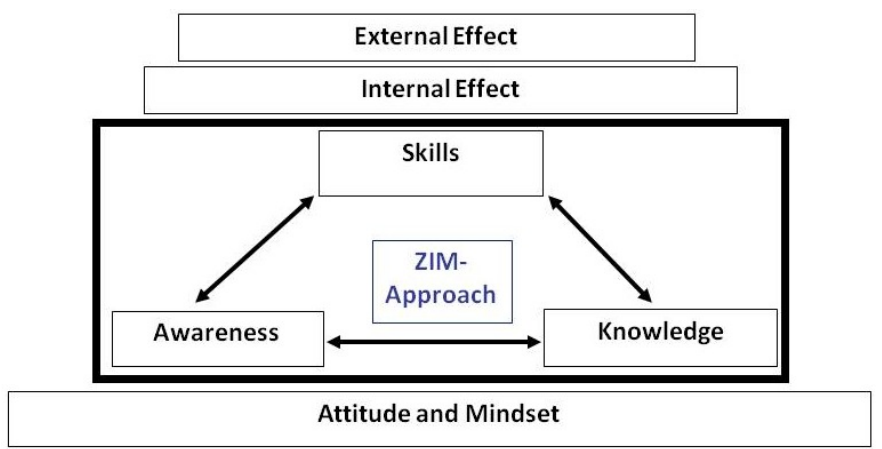

Fig. 2. Scientific training approach of the ZIM 2.
According to this theoretical model, a new blended learning concept was implemented and also different analysis tools of cross-cultural training were developed within the framework of CCBM-TRAILS project.

\section{Intercultural Analysis Instruments}

In terms of problems in a cross-cultural work environment, many human resource departments observe a demand for different analysis tools to screen the qualification of their employees and deliver specific training for the needs of different target groups. Previous analysis tools often showed deficits in conceptual and methodological aspects and also displayed problems in the transfer from research to practice. Based on the outcomes of two ZIM studies, various analysis instruments shall be developed. The acquisition of different components of the ZIM approach should allow for an analysis of the participants and groups of participants. Furthermore, it can be used as an evaluation tool to show the success of the teaching process. In the CCBM-TRAILS project, all the deficits presented by previous tools served as the base for the development of new concepts for different analysis and didactical instruments in a cross-cultural context:

The Intercultural Sensibility Analyzer (ISA) was developed in 2010, based on the Intercultural Development Inventory by Hammer, Bennett and Wiseman [15]. The ISA is based on current theories; it fulfils methodical criteria of validity and reliability for a psychometric test. The ISA examines the sensibility of intercultural competence from the individual level to cultural differences. The ISA is similar to the cultural assimilator method. Action strategies cannot be measured with general ratings. Action strategies have to be noticed in a specific context. For this reason, this method works with "critical incidents". This means that case studies are shown to the user and problematized. Students can choose an answer with the help of different options of solutions. With the aid of ten case studies, the method is able to test the intercultural sensibility of the users. The theoretical basic concept of the Cultural Preference Profile (CPP) contains eight cultural dimensions, which depend on the work of Hall, Hofstede, Trompenaars and the GLOBE study. Firstly, the CPP is able to construct a personal profile of each participant. This individual profile is oriented to the cultural dimensions and declares individual preferences and characteristics of each participant. The results of each participant are compared with that of other participants. The analysis tools are intended to be an evaluation screening for intercultural competence and an evaluation tool for apprenticeship. Especially in connection with admission and measurement of aims of competence in individual modules, the benefit is high. The screening can be used for the evaluation of intercultural development through a stay abroad and teaching activities by a pretest-posttest study.

\section{BLENDED LEARNING: E-LEARNING AND TRAINING}

International enterprises, organizations and universities more and more observe the need for the implementation of blended learning concepts for virtual teams in order to increase cultural competence. Blended learning here means 
the combination of face-to-face training and online activities mostly enhanced through coaching and consultancy or other sorts of company or team interrelation. The structure of the blended learning concept in the CCBM-TRAILS project can be divided into the areas: analysis tools, e-learning, on site face-to-face training and coaching. Information-based elearning is held before the face-to-face training. The exercisebased training is held after the e-learning. The coaching and consultancy go along the full process of learning and support the teams afterwards. The composition allows the integration of whole study processes at cognitive, affective and conative levels. Through allocation of selected theoretical basics in the first e-learning section, the participants are offered an easy and quick jump into intercultural and virtual team themes. The trainer has the chance to use the key basics as a premise for the face-to-face phase. At this stage, especially the cognitive level is mediated. At this stage, the analysis tools also take part. The analysis results of the individual and the team provide important information about the participants to the trainer, who uses this information to customize the next steps in the e-learning and his design of the face-to-face training. Experience-oriented studying during the face-to-face training allows for emotional experiences and improves intercultural appreciation and virtual team comprehension. These individual emotional experiences are very important for the participants. The CCBM-TRAILS project allows the trainer to combine an attendance and an off-campus phase. The focal point is the competence development, the emotional experience and the development of action-oriented know-how. The exercise-based e-learning broadens the emotional, situation specific and action-oriented dimension of intercultural and virtual team training through cognitive and action specific components. The experience acquired during the face-to-face training can be deepened and improved, as well as transferred into intercultural and virtual team settings. The content can be adapted individually. With the help of the different methods affective, cognitive and conative processes are simulated, which improves the transfer of knowledge among participants. Additionally, there is a high demand for multimedia case studies such as films and animations. The CCBM-TRAILS project includes several media types for case studies and learning.

\section{CONCLUSION}

The CCBM-TRAILS Cross-Cultural Management Business and Virtual Communication and Awareness Analysis Tool provides a knowledge tool in the form of culturally transferable application and blended learning conception. In the analysis and training area, the CCBM-TRAILS project is systematically divided into the necessary sections of the cultural competence and the virtual team communication. The core of the platform is the neuro-emotional blended learning methodologies that exploit the technical possibilities of digital applications to allow students to go through an optimal and accompanying learning with individualized feedback. This not only offers the preference and emotion-related profiles from the analysis area, but also provides immediate feedback to the qualitative level of learning success. Thus, a country-specific joint working group can compensate its cross-cultural and virtual team communication deficits through training and can efficiently follow the virtual cross-cultural business communication. The modular and user-efficient design of the application allows using a matrix to create individual training trails. Future technical interfaces, such as mobile clients for various cultural and country-specific uses, allow integrating different types of media to meet the different reception levels. The CCBM-TRAILS project is demand-oriented. Different application scenarios have been explored in the present article. The further research will be related to multi-lingual train-thetrainer interaction.

\section{REFERENCES}

[1] Scheitza, Alexander, Interkulturelle Kompetenz: Forschungsansätze, Trends und Implikationen für interkulturelle Trainings, In: Otten, Matthias / Scheitza, Alexander / Cnyrim, Andrea (Hrsg.) Interkulturelle Kompetenz im Wandel 1: Grundlegungen, Konzepte und Diskurse, IKO Verlag, Frankfurt am Main, 2009.

[2] Picot, Arnold; Reichswald, Ralf, 1999, in: Heinz, Ulrike, Führung und Kooperation als Erfolgsfaktoren in innovativen F\&E-Projekten auf elektronischen Plattformen, Technischen Universität Berlin, 2005, pp. 130

[3] Castells, Manuel, The Network Society: From Knowledge to Policy. The Network Society: From Knowledge to Policy. Eds. Manuel Castells and Gustavo Cardoso. Washington, DC: John Hopkins Center for Transatlantic Relations, 2006, pp. 3-21.

[4] S. Weisband, Leadership at a distance; Research in technologicallysupported work. New York: Lawrence Erlbaum Associates, Inc., 2008.

[5] Konradt, Udo; Köppel, Petra, Erfolgsfaktoren virtueller Kooperationen Best Practices von Microsoft Deutschland GmbH und Telefonica O2 Germany GmbH \& Co. OHG. Bertelsmann Stiftung. Gütersloh, 2008, p. 14.

[6] Wong, Sze-Sze; M. Burton, Richard, Virtual Teams: What are their Characteristics, and Impact on Team Performance? In: Computational \& Mathematical Organization Theory, Vol.6, Nr. 4, 2000, pp. 339-360. http://dx.doi.org/10.1023/A:1009654229352

[7] Lojeski, Karen Sobel, Leading the virtual workforce: how great leaders transform organizations in the $21^{\text {st }}$ century. Microsoft Executive Leadership series; 14. Hoboken, New Jersey: John Wiley \& Sons, 2010.

[8] L. Duarte, Deborah, Snyder, Nancy Tennant, Mastering virtual teams: strategies, tools, and techniques that succeed. Third Edition. San Francisco: Jossey-Bass. 2006.

[9] L. Griffith, Terri, A. Mannix, Elizabeth, A. Neale, Margaret, Conflict and Virtual Teams. In: Gibson, Christina B.; Cohen, Susan G., Editors: Virtual Teams that work - Creating Conditions for Virtual Team Effectiveness, San Francisco: John Wiley \& Sons., 2003, pp. 335-352.

[10] Lipnack, Jessica; Stamps, Jeffrey: Virtual Teams: People Working across Boundaries with Technology. Second Edition. New York: John Wiley \& Sons, 2000.

[11] Herrmann, Dorothea; Hüneke, Knut; Rohrberg, Andrea, Führung auf Distanz - Mit virtuellen Teams zum Erfolg. Wiesbaden: Betriebswirtschaftlicher Verlag Dr. Th. Gabler, 2006.

[12] Al-Ani, Ban; Horspool, Agnes; Bligh, C. Michelle, Collaborating with 'virtual strangers': Towards developing a framework for leadership in distributed teams. In: SAGE journals, Leadership August 2011, Vol. 7 (3), 2011, pp. 235, 219-249.

[13] Deardorff, Darla, Interkulturelle Kompetenz -Schlüsselkompetenz des 21. Jahrhunderts? Thesenpapier der Bertelsmann Stiftung auf Basis der Interkulturellen-Kompetenz-Modelle von Dr. Darla K. Deardorff, Bertelsmann-Stiftung, 2006.

[14] Berninghausen, Jutta, Der Spagat zwischen Reproduktion und Überwindung von Klischees. In Bolten, Jürgen / Rathje Stefanie (Hrsg.) Interkulturelle Kompetenz und Employability, intercultural journal, Jahrgang 6, Ausgabe 3, 2007.

[15] R. Hammera, Mitchell; J. Bennettb, Milton; Wiseman, Richard: Measuring intercultural sensitivity: The intercultural development inventory, International Journal of Intercultural Relations, Pergamon, Elsevier Ltd., 2003. 


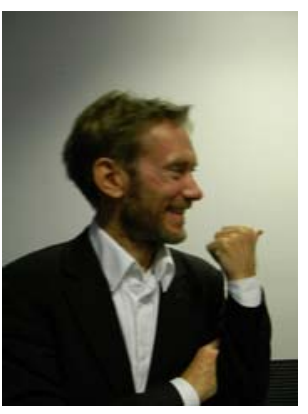

Martin Koplin obtained a Master's Degree in Cultural Studies with a focus on digital media, communications, sociology and art in the 1990s. Then he also completed a programme in organizational studies and received a Master's Degree in European Labour Studies. He is certificated coach and consulter in the neuroemotional organizational development. $\mathrm{He}$ is currently elaborating his doctoral thesis in computer sciences under the guidance of Prof. Frieder Nake.

$\mathrm{He}$ is the Director of the M2C Institute for Applied Media Technology and Culture at the University of Applied Sciences Bremen. He is a Lecturer at the University of Applied Sciences for Digital Media and Virtual Team Communication and a Scientist in Residence at the BxmC of the Polytechnic Institute of New York University. He is a Scientific Consultant and Head of the think tank "Think BETA" (BMBF-funded) for the elaboration of ICT tools in order to develop smart cities. He is the Head of the international SMARTIC innovation network for countries from Europe and the Mediterranean.

He was Researcher at the e-Culture Factory of Fraunhofer IAIS and at the AGIS Institute, University of Bremen.

Research interests include development of new concepts and technologies for communication and innovation in topics of social change, participation and organization. Other of his projects are Betaville for participatory urban development and artMUSE: designing new ways of communicating with digital media, virtual work and the reflection of social, organizational and cultural participation locally and globally, interactive systems, mixed user environments, eLearning and museum media, and the appropriate skills for business communication, media innovation and cultural theory.

Martin Koplin published over 30 articles and his work awarded several prizes for innovation in Europe and Germany: for R\&D Project TRAILS "Best of 2012" Award in the category of IT Innovation from the German Initiative Mittelstand; for R\&D Project eMUSE: "Best of 2012" Award in the category of IT Innovation from the German Initiative Mittelstand; for R\&D Project MORITZ: "Best Practice in Creativity and Innovation of EU Programmes" Award from the European Commission in 2009; for R\&D Project MOMEUS: "Annual Multimedia Germany 2009" Award; for R\&D Project deine-story.de: "European Annual Logo-Design 2008" Award.

Contact information:

Martin Koplin

M2C Institute for Applied Media Technology and Culture at the University of Applied Sciences Bremen

Address: Flughafenallee 10, Raum 317, DE-28199 Bremen

E-mail: mkoplin@uni-bremen.de, Phone: +49-421-5905-5402,

Web-site: http://m2c-bremen.de

Jochen Schiffmann obtained a Master's Degree in Cultural Studies (majoring in Ethnology, Economics, and Project Management) from the University of Bremen. Jochen Schiffmann worked for two years in the development cooperation sector and spent three months as a scholarship holder in Kazakhstan within the framework of the project "Deutsche Gesellschaft für Internationale Zusammenarbeit" (GIZ) former InWent. Since 2010, he has been working as a Researcher and Scientific Assistant at the Centre for Intercultural Management (Zentrum für Interkulturelles Management, ZIM). His research focuses on the conception of learning concepts for intercultural competence. He has mainly been involved in creating the analysis instruments and the blended learning within the framework of the CCBM-TRAILS project.

Contact information:

Jochen Schiffmann

Tel.: +49 (0)421 - 5905-4287, Fax: +49 (0)421 - 5905-4783, Mobile: +49 (0)

176 / 32110037, E-mail: jochen.schiffmann@hs-bremen.de

Simone Müller, Master (Diploma) of Business Administration (1997, Christian-Albrechts-University of Kiel), Erasmus scholarship (1993/94, Jean Moulin III Universität, Lyon in France). Certified NLP Coach and Master of NLP/Timeline Therapy/Hypnosis (American Board of NLP); Certified Coach at the Institute for Systemic Solutions in Wiesloch.

Simone Müller is a Consultant and Coach (since 2009) at the internationa companies (FTSE) focussing on distance leadership and working in virtual teams.

Simone Müller is a Scientific Researcher (since 2009) at the M2C Institute for Applied Media Sciences at the University of Applied Sciences, Bremen.
She is an Assistant Professor (2010) at the University of Applied Sciences, Bremen; she gives lectures related to different aspects of virtual team work environments.

She worked as an International Relations Manager (1997-2008) at a global corporation (FMCG); extensive work experience in managing and building virtual international teams; expat assignment in London (2001-2006); further work experience in Belgium, Italy, France, Sweden, Switzerland, India and the United States.

Current and previous research interests include virtual teams, leadership, future working structures, occupational psychology

E-mail: mail@simonemueller.eu

Helmut Eirund received a Diploma in Computer Science in 1985; until 1988 he worked at TA/Olivetti research lab and was responsible for multimedia document management; until 1991 he was a Research Assistant at the University of Oldenburg and holds a Doctoral Degree in the field of multimedia document management. Until 1994 he worked at OFFIS research institute, his responsibilities involved the elaboration of multimedia development tools. From 1994 to 2001 he was a Professor at Hochschule Harz, University of Applied Studies and Research. Since 2001 he is a Professor at the Hochschule Bremen, University of Applied Sciences. Project and research activities include mobile applications, multimedia systems, and electronic entertainment. Helmut Eirund is the Scientific Director of the M2C Institute for Applied Media Technology and Culture and he is the author of 30 peer-reviewed papers and 4 books.

Contact:

Prof. Dr. Helmut Eirund

Hochschule Bremen, University of Applied Sciences Zentrum für Informatik und Medientechnologie ZIMT

E-mail: eirund@informatik.hs-bremen.de

Web-site: http://www.informatik.hs-bremen.de/ eirund

Web-site: http://m2c-bremen.de

Jutta Berninghausen holds a Doctoral Degree in Educational Science. Jutta Berninghausen conducted research on gender and self-regulating communities in Central Java (Indonesia). She lived for 9 years in Indonesia and worked for German and international organizations in the development corporation sector; always dealing with the topics of intercultural competence she developed her own approaches and methods for training.

Today Jutta Berninghausen is a Professor of Intercultural Management and Vice-Rector for International Relations at the University of Applied Science Bremen. She gives lectures related to intercultural competence, cross-cultural management, diversity-management and cultural science of Southeast Asia. Besides, she is works as an Evaluator, Supervisor, and Coach for international organizations in different sectors.

She is a Board Member of the Akademie für Interkulturelle Studien, Würzburg (Academy of International Studies); Zentrum für Interkulturelles Managements, Bremen (Centre for Intercultural Management); and Hochschulverband für Interkulturelle Studien e.V. (IKS) (University Association of Intercultural Studies).

Contact information:

Prof. Dr. Jutta Berninghausen

Konrektorin für Internationales

Address: Grünenstraße $33-36$

28199 Bremen, Phone: +49 4215905 2142, E-mail: Jutta.Berninghausen@hsbremen.de

Martina Fetting received a Master's Degree in Philosophy from the University of Bremen in 2006. PhD thesis: "Legitimation and Legitimacy of the Last German Monarchs (History), tutor Prof., Dr.phil. Wolfgang Reinhard (scholarship at the Max-Weber-Kolleg for Cultural and Social Sciences (University of Erfurt).

She is a Scientific Researcher at the M2C Institute for Applied Media Technology and Culture at the University of Applied Sciences Bremen. She participated in the Regialog programme (Qualification in Cultural Management and Cultural Marketing). She is a Tutor at the University of Applied Sciences, Bremen. Martina Fetting also takes part in various scientific projects.

Scientific publication: Fetting, M., Grossherzoglicher Ehebruch im Blickpunkt grosser Politik. Ein Beitrag zum monarchischen Selbstverständnis im zweiten deutschen Kaiserreich. Historische Anthropologie, 2009, Series 17, Volume 3, pp. $320-344$.

Current and previous research interests: representation, legitimacy and selflegitimacy, participatory urban development, post-colonial theory 
Contact information:

E-mail: fetting@m2c-bremen.de, Phone: +49-421-5905-5470

Martina Fetting

M2C Institute for Applied Media Technology and Culture at the University of

Applied Sciences Bremen

Address: Flughafenallee 10, Raum 317, DE-28199 Bremen

Martins Koplins, Johens Šifmans, Simone Millere, Helmuts Eirunds, Jutta Berninghausena, Martina Fettinga. CCBM - TRAILS: starpkulturāla biznesa un virtuālu komandu komunikācijas treniṇu programma

TRAILS ir starpkulturāla biznesa un virtuālu komandu komunikācijas treninu un elektroniskas apmācības platforma, kas balstīta uz daudzpusēju mācišanās metodoloǵiju. Tā sastāv no analīzes, izpratnes un treniņu mācību līdzekḷiem. Šì platforma ir radusies no pētijumiem M2C Mediju Tehnoloǵiju Institūtā un Brēmenes Zinātṇu Universitātes Starpkulturālā menedžmenta centrā. Projekts ir Eiropas "Think BETA - Evolution of Smart Cities" domnīcas stratēǵijas "Smart Cities - Smart Culture - Smart Humans" rezultāts. TRAILS platforma arī funkcionē kā padomdevējs organizatoriskā darba optimizācijā. TRAILS projekta iespējamie praktiskie pielietojumi tiek attīstîti, sadarbojoties ar konsultantiem un treneriem, lai tas tiktu pielietots nākotnes CCBM sistēmā. Gala lietotājs pildīs uzdevumus virtuālā darba plūsmas, sociālās navigācijas un starpkulturālās darbības sektoros. Tālāku konsultantu un treneru kvalifikāciju atbalstīs starpkulturāla sadarbība starp ekspertiem, kas komunicēs par tehniskām un metodologiskām mācišanās sastāvdạ̦ām. Nākotnē projekts kḷūs par daudzfunkcionālu Eiropas līmeṇa līdzekli vairākās valodās, kas būs gatavs ieviešanai visur Eiropā akadēmiskā treniṇa un profesionālās attīstības programmās industrijas menedžeriem, biznesam un nevalstiskajām organizācijām.

Мартин Коплин, Йохен Шиффманн, Симоне Муллер, Хелмут Еирунд, Ютта Бернингхаусен, Мартина Феттинг. CCBM - TRAILS: межкультурная программа коммуникационных тренировок бизнеса и виртуальных команд

TRAILS: является межкультурной электронной платформой обучения бизнеса и виртуальных команд, которая основывается на разнообразную методологию обучения. Платформу составляют тренировочные и аналитические учебные пособия. Платформа разработана на основе исследований проведённых в Институте Технологий СМИ М2С и в межкультурном центре менеджмента Бременского Научного университета. Проект является результатом стратегии мозгового центра "Smart Cities - Smart Culture - Smart Humans" Европейской "Think BETA - Evolution of Smart Cities". Платформа TRAILS функционирует также как и советчик по оптимизации организаторских работ. Практическое использование проекта развивается, сотрудничая консультантами и тренерами, с целю использования проекта в следующих системах ССВМ. Конечный пользователь выполнит задачи в пределах секторов действительных потоков работы, социальной навигации и межкультурного действия оптимизированным способом. Дальнейшая квалификация тренеров и консультантов будет поддержана и оживлена межкультурным взаимодействием между экспертами, общающимися о технических и методологических компонентах изучения. В будущем проект будет многоязычным, многофункциональным европейским инструментом, готовым к внедрению во всей Европе в академических и программах профессионального развития для менеджеров в промышленности, бизнесе и неправительственных организациях. 